\title{
A Study on the Biosynthesis of Tremerogen $A-10$, a Polyisoprenyl Peptide Mating Pheromone of Tremella mesenterica, Using an Inhibitor of Mevalonate Synthesis
}

\author{
Tokichi Miyakawa, Ryo Miyama, Masahiko Tabata, \\ Eiko TsuchiYa and Sakuzo Fukui \\ Department of Fermentation Technology, Hiroshima University, \\ Saijo, Higashi-Hiroshima 724, Japan
}

Received September 13, 1984

\begin{abstract}
Tremerogen $A$-10 is an S-polyisoprenyl peptide mating pheromone secreted by the $A B$ cells of the heterobasidiomycetous yeast Tremella mesenterica. We investigated the feasbility of the use of compactin (ML 236-B), a potent inhibitor of mevalonate synthesis in mammalian cells, for the study of the mating pheromone production. Compactin specifically inhibited mevalonate synthesis of the yeast cells without affecting protein synthesis. The secretion of tremerogen $A-10$ was effectively blocked by the drug. Accumulation of a large precursor polypeptide (M.W. 28,000) for the mature pheromone (M.W. 1,480) in the membrane fraction of compactin-treated cells was demonstrated by immunoprecipitation of ${ }^{35} \mathrm{~S}$-labeled proteins. The results suggested that the addition of the nonpolar residue to a polypeptide precursor is important for the production of tremerogen $A-10$, especially in the intracellular transport and processing of the precursor molecules.
\end{abstract}

Sexual conjugation of haploid cells of two compatible mating types $(A B$ and $a b)$ of the heterobasidiomycetous yeast Tremella mesenterica is mediated by mating-type specific diffusible pheromones. ${ }^{1)}$ The pheromones elicit metabolic and morphological changes in the target cell having the mating type opposite to the pheromone producer cell. ${ }^{1 \sim 3)}$ Tremerogen $A$-10 (TA-10), ${ }^{4)}$ the mating pheromone produced by the $A B$ cells, has been purified to homogeneity and its chemical structure is a lipopeptide with an S-polyisoprenyl cysteine residue at the carboxy terminus of the peptide (Fig. 1). The nonpolar residue of the pheromone is indispensable for its biological activity. ${ }^{5)}$ The residue may also be important for the production of the mating pheromone, especially in the process of secretion across the membrane. The assessment of the significance of the nonpolar residue for the secretory process of TA-10 would be facilitated by the use of inhibitors of the synthesis of polyisoprene.

Compactin (ML 236-B) is a potent competitive inhibitor of 3-hydroxy-3-methyl- glutaryl coenzyme A (HMG CoA) reductase in mammalian cells ${ }^{6)}$ and has been widely used to study biochemical and physiological effect of the inhibition of the synthesis of mevalonate and its metabolites. In order to test the possibility of exploiting compactin as a tool for the study of TA-10 synthesis, we investigated the biochemical effect of the drug on this organisms and the effect of the drug on the production of TA-10. In this paper we show that the drug specifically inhibits the synthesis of mevalonate and that TA-10 production is blocked with accumulation of a membrane-bound very high molecular weight precursor.

\section{MATERIALS AND METHODS}

Microorganisms and growth conditions. Haploid strains of Tremella mesenterica UBC 6106-1 (mating type $A B$ )

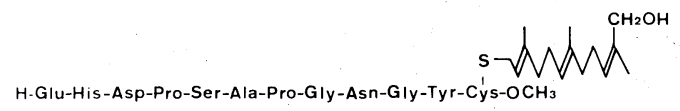

FIG. 1. Tremerogen $A-10,{ }^{4)}$ Mating Pheromone Produced by Mating Type $A B$ Cell of Tremella mesenterica. 
and -2 (mating type $a b$ ) described in our previous paper ${ }^{7)}$ were used. The cells were cultured in $5 \mathrm{ml}$ of minimal medium $^{7)}(\mathrm{MM})$ at $28^{\circ} \mathrm{C}$ in culture tubes $(1.8 \mathrm{~cm}$ by $18 \mathrm{~cm})$ with agitation. Assay of the biological activity of TA-10 was done by serial dilution. ${ }^{7)}$

Incorporation of $\left[{ }^{14} \mathrm{C}\right]$ acetate and $\left[{ }^{14} \mathrm{C}\right]$ mevalonate into nonsaponifiable lipids and fatty acids. To the cultures of $A B$ cells preincubated with the indicated concentrations of compactin for $1 \mathrm{~h}$ at $28^{\circ} \mathrm{C}$ with shaking, was added $0.5 \mu \mathrm{Ci}$ of either $\left[1-{ }^{14} \mathrm{C}\right]$ acetate or $\left[5-{ }^{14} \mathrm{C}\right]$ mevalonate. After $8 \mathrm{~h}$ of further incubation, the cells were harvested by centrifugation and washed once with $5 \mathrm{ml}$ of water for determination of the radioactivity incorporated into nonsaponifiable lipids and fatty acids as follows: the labeled cells were suspended in $1 \mathrm{ml}$ of $5 \% \mathrm{KOH}$-ethanol (w/v) and heated in a water bath at $75^{\circ} \mathrm{C}$ for $90 \mathrm{~min}$ to saponify cellular lipids. The resulting suspension was centrifuged at $6,000 \times g$ for $10 \mathrm{~min}$ to remove cell debris. Nonsaponifiable lipids in the supernatant solution were extracted three times with $1 \mathrm{ml}$ portions of petroleum ether. The aqueous phase was then acidified by the addition of $6 \mathrm{~N} \mathrm{HCl}$, followed by extraction with petroleum ether as above to obtain fatty acids. The pooled organic phase was evaporated to dryness, dissolved in a small volume of chloroform-methanol $(2: 1, \mathrm{v} / \mathrm{v})$, spotted onto filter paper (2-cm diameter) and the radioactivity was determined in a liquid scintillation counter.

\section{RESULTS AND DISCUSSION}

First, we tested the effect of various concentrations of compactin on the growth and extracellular production of TA-10 by $A B$ cells (Fig. 2). We previously demonstrated that TA10 is initially synthesized as high molecular weight precursors when the cell growth starts to decline toward the end of logarithmic phase, followed by secretion of the mating pheromone into the medium for about $30 \mathrm{~h}$, and the pheromone production ceases thereafter. ${ }^{10)}$ Thus, compactin was added to an exponentially growing cell culture at a cell density of $1 \times 10^{7}$ cells $/ \mathrm{ml}$, a time before the precursor accumulation, and cultivated for $72 \mathrm{~h}$ until the pheromone production was virtually completed in control culture. In the absence of compactin, the cell number increased about 18 -fold during the cultivation period. The cell growth was inhibited $50 \%$ by the drug at a concentration of $100 \mu \mathrm{g} / \mathrm{ml}$ (Fig. 2). The concentrations of the drug required for the growth inhibition of this organisms was much higher

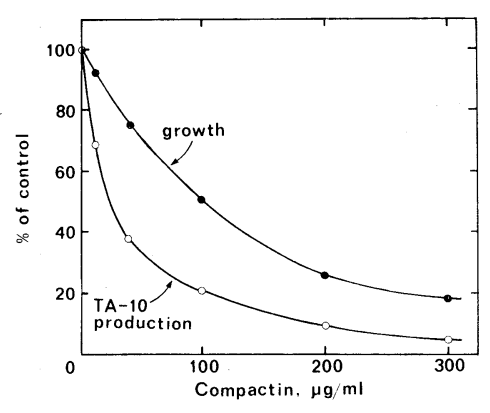

FIG. 2. Effects of Various Concentrations of Compactin on the Growth and TA-10 Production.

Cells (mating type $A B$ ) growing exponentially in MM were diluted with fresh $\mathrm{MM}$ to adjudt the cell concentration to $1 \times 10^{7}$ cells $/ \mathrm{ml}$. To the $5-\mathrm{ml}$ cell suspensions were added various concentrations of compactin, and the cells were cultivated in test tubes $(1.8 \mathrm{~cm}$ by $18 \mathrm{~cm})$ at $28^{\circ} \mathrm{C}$ for $72 \mathrm{hr}$ with shaking. Cell number was counted under a microscope using a hemocytometer. Pheromone activity was determined as described in Materials and Methods. Compactin had no influence on the biological assay of the pheromone at the drug concentrations used.

\section{Table I. Cell Growth and TA-10 Production of $A B$ Cells Cultivated in the Presence of Compactin and Mevalonate}

To 5-ml cultures of $A B$ cells in the logarithmic phase of growth were added compactin and/or mevalonate to final concentrations of $100 \mu \mathrm{g} / \mathrm{ml}$ and $300 \mu \mathrm{g} / \mathrm{ml}$, respectively. The initial cell concentration was adjusted to $1 \times 10^{7}$ cells $/ \mathrm{ml}$, and the cells were cultivated for $72 \mathrm{hr}$. Cell number and mating pheromone activity were determined as described in Materials AND Methods. Compactin and mevalonate had no influence on the biological assay of the pheromone at the concentrations used.

\begin{tabular}{lcc}
\hline Addition & $\begin{array}{c}\text { Cell number } \\
(\text { cells/ml })\end{array}$ & $\begin{array}{c}\text { TA-10 production } \\
(\mathrm{U} / \mathrm{ml})\end{array}$ \\
\hline None & $1.8 \times 10^{8}$ & 46 \\
Compactin & $8.0 \times 10^{7}$ & 10 \\
Mevalonate & $1.8 \times 10^{8}$ & 42 \\
Compactin + & $1.7 \times 10^{8}$ & 43 \\
$\quad$ mevalonate & & \\
\hline
\end{tabular}

than those reported for mammalian cells, ${ }^{6)}$ possibly due to poor permeability of the drug through the cell surface. The pheromone production was more sensitive to compactin than cell growth: $50 \%$ inhibition of the pheromone production was attained at about $12 \mu \mathrm{g} / \mathrm{ml}$ of compactin, in contrast to $100 \mu \mathrm{g} / \mathrm{ml}$ for $50 \%$ 


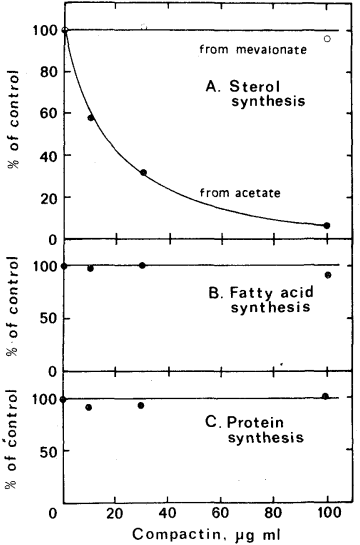

FIG. 3. Effects of Various Concentrations of Compactin on the Incorporation of $\left[{ }^{14} \mathrm{C}\right]$ Acetate (O) and $\left[{ }^{14} \mathrm{C}\right]-$ Mevalonate (O) into sterols (A), on $\left[{ }^{14} \mathrm{C}\right]$ Acetate into Fatty Acids (B), and on $\left[{ }^{3} \mathrm{H}\right]$ Leucine into Protein (C).

Before addition of labeled precursors $\left(0.5 \mu \mathrm{Ci}\right.$ of $\left[{ }^{14} \mathrm{C}\right]-$ acetate, $0.5 \mu \mathrm{Ci}$ of $\left[{ }^{14} \mathrm{C}\right]$ mevalonate or $5 \mu \mathrm{Ci}$ of $\left[{ }^{3} \mathrm{H}\right]$ leucine), $A B$ cells $\left(4 \times 10^{8}\right.$ cells $)$ in $5 \mathrm{ml}$ of $\mathrm{MM}$ were preincubated with the indicated concentrations of compactin for $1 \mathrm{hr}$ at $28^{\circ} \mathrm{C}$ with shaking. Incorporation of the radioactive precursor was performed for $8 \mathrm{hr}$ under the above conditions.

inhibition of cell growth. Both cell growth and pheromone production affected by $100 \mu \mathrm{g} / \mathrm{ml}$ of compactin were restored to normal levels by mevalonate added to the medium (Table I). The results indicated that compactin specifically inhibited the mevalonate synthesis of this organisms by similar mechanisms as in mammalian cells.

To further test if compactin inhibits the synthesis of mevalonate, sterol syntheses in the presence of the drug from the two radiolabeled precursors $\left[{ }^{14} \mathrm{C}\right]$ acetate and $\left[{ }^{14} \mathrm{C}\right]$ mevalonate were compared. As shown in Fig. 3A, the incorporation of $\left[{ }^{14} \mathrm{C}\right]$ acetate into sterols was strongly inhibited by compactin. The concentration of the drug for $50 \%$ inhibition of sterol synthesis from acetate was close to that of TA-10 production (Fig. 2). In contrast, sterol synthesis from $\left[{ }^{14} \mathrm{C}\right]$ mevalonate was not inhibited by the drug at the concentrations tested $(0 \sim 100 \mu \mathrm{g} / \mathrm{ml})$ (Fig. 3A). Thus, it was concluded that the synthesis of mevalonate from acetate was specifically inhibited by compactin. Protein synthesis was not inhibited by

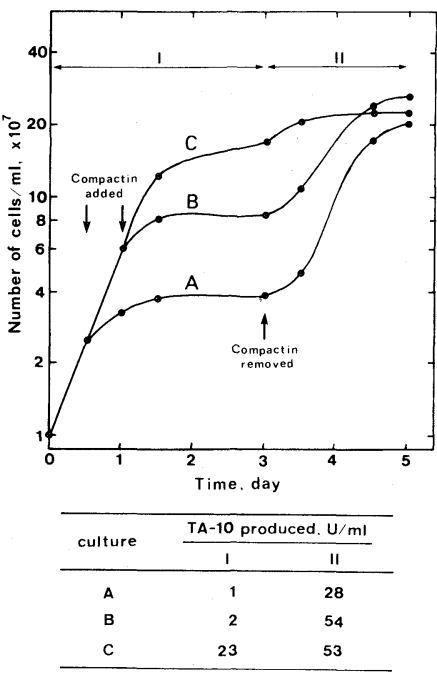

FIG. 4. Reversibility of the Inhibitory Effect of Compactin on the Growth and TA-10 Production.

The cells were grown as described in Fig. 2. At the times indicated by the arrows, compactin was added to a final concentration of $100 \mu \mathrm{g} / \mathrm{ml}$. After $72 \mathrm{hr}$ of incubation, the cell cultures were centrifuged at 3,000 rpm for $10 \mathrm{~min}$ and the supernatant fraction was isolated and saved for pheromone assay (medium I). The cells were washed once with MM, suspended in the same volume $(5 \mathrm{ml})$ of fresh MM and cultivated further for $48 \mathrm{hr}$. Cell-free culture medium was isolated as described above for pheromone assay (medium II).

compactin (Fig. 3C). These properties are useful in using the drug to investigate TA-10 production by specifically inhibiting the synthesis of the polyisoprene moiety of the pheromone.

Reversibility of the inhibition by compactin of cell growth and TA-10 production was examined. As seen in Fig. 4, when the cells cultivated in the presence of $100 \mu \mathrm{g} / \mathrm{ml}$ of compactin were transferred to fresh medium free of the drug, the cells resumed exponential growth after a short lag period. A significant amount of mating pheromone was produced during cultivation for $48 \mathrm{~h}$ following the shift to new medium free of the drug (Fig. 4). The ready reversibility of the inhibition by compactin in the yeast cells is in accord with the competitive inhibitory mechanism of compactin for $\mathrm{HMG}$ CoA reductase in mammalian cells. $^{6)}$ 


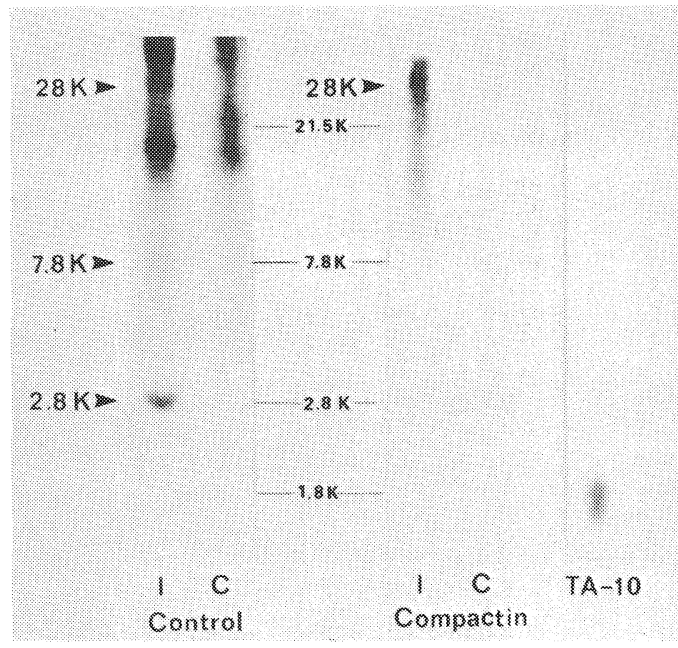

FIG. 5. Analysis of ${ }^{35} \mathrm{~S}$-Labeled TA-10 Precursors Formed in the Presence and Absence of Compactin.

Details of the procedure for the cell labeling, subcellular fractionation, immunoprecipitation, and gel electrophoresis were described elsewhere. ${ }^{10)}$ Here, only a brief description of the procedure is given. The cells in the logarithmic phase of growth were radiolabeled with 0.3 $\mathrm{mCi}$ of ${ }^{35} \mathrm{SO}_{4}{ }^{2-}$ for $24 \mathrm{hr}$ in low sulfate minimal medium in the presence or absence of $100 \mu \mathrm{g} / \mathrm{ml}$ of compactin. The ${ }^{35} \mathrm{~S}$-labeled cells were distrupted by vigorous agitation with glass beads. The cell debris was collected and solubilized in $1 \%$ NP-40 and undissolved materials were removed by high-speed centrifugation $(100,000 \times g, 60$ $\mathrm{min})$. Immunoprecipitation was done by the addition of $20 \mu \mathrm{l}$ of anti-TA-10 antiserum ${ }^{11)}$ and Protein A-Sepharose 4B. After washing the beads extensively, the bound peptides were eluted and analyzed by sodium dodecyl sulfate (SDS)-urea polyacrylamide gel electrophoresis. ${ }^{12)}$ The bands of radioactive peptides were detected by fluorography. I, precipitated with the immune serum; C, precipitated with control (non-immune) serum. Molecular weight markers used were soybean trypsin inhibitor $(21.5 \mathrm{~K})$, and cyanogen bromide digested fragments of cytochrome $c(\mathrm{c}-\mathrm{I}[7.8 \mathrm{~K}], \quad \mathrm{c}-\mathrm{II} \quad[2.8 \mathrm{~K}]$ and c-III $[1.8 \mathrm{~K}])$.

We previously showed by radioimmunoassay with antibody directed against the peptide moiety of TA-10 that biologically inactive TA-10 analogue(s) accumulate in the cell during the inhibition of TA-10 production by compactin. ${ }^{10)}$ The results indicated that TA-10 precursors accumulate as the result of inhibition of mevalonate synthesis. Thus, molecular species of TA-10 precursors which accumulate in the cell during inhibition of TA-10 production were analyzed and compared with those present in untreated cells. TA-10 precursors in the cell extracts of ${ }^{35} \mathrm{~S}$-labeled cell were isolated by immunoprecipitation and analyzed by SDS-urea polyacrylamide gel electrophoresis. The fluorographic pattern in Fig. 5 shows the presence of precrusors of various sizes in the control cells. Polypeptide species of MW 28,000, 7,800, and 2,800 were specifically precipitated by the immune serum. In contrast, only the MW 28,000 species was immunoprecipitated in compactin-treated cells. The results suggested that TA-10 (MW 1,480 ) was produced as a result of processing of very high molecular weight peptides and that compactin blocked secretion of TA-10 by inhibition of the processing, with intracellular accumulation of the MW 28,000 precursor. Thus, the addition of polyisoprene residue(s) to the precursor peptide appeared to be necessary for further processing of the high molecular weight precursor molecule. Absence of the nonpolar residue in the MW 28,000 molecule still needs to be demonstrated. In the presence of tunicamycin, an inhibitor of protein glycosylation, ${ }^{13}$ ) however, a polypeptide of MW 12,000 accumulated. ${ }^{10)}$ The difference of molecular species accumulated by the two inhibitors indicated that inhibition of TA-10 synthesis by compactin is not due to inhibition of protein glycosylation through inhibition of the synthesis of carrier lipid, but that the drug inhibits farnesylation of the precursor. The MW 28,000 peptide, a putative unfarnesylated precursor, was present exclusively in the membrane fraction and was absent in the cytosol fraction (unpublished data), indicating that the site of addition of the nonpolar residue is on the membrane. Detailed studies of the biosynthesis and secretion of TA-10 with various drugs including compactin will be reported elsewhere. ${ }^{10)}$

Acknowledgment. We are grateful to Dr. A. Endo of Tokyo Noko University for the generous gift of ML236-B (Compactin) and for technical guidances. This work was supported in part by a Grant-in-Aid for Scientific Research (No. 544009) from the Ministry of Education, Science and Culture of Japan. 


\section{REFERENCES}

1) R. J. Bandoni, Can. J. Bot., 43, 627 (1965).

2) E. Tsuchiya, T. Miyakawa, K. Suzuki, K. Hayakawa and S. Fukui, "Advances in Biotechnology," Proceedings of the 6th International Symposium on Yeasts and the 5th International Fermentation Symposium on Yeasts, ed. by M. M. Young, Pergamon Press, Ontario, 1981, p. 257.

3) A. Hirata, E. Tsuchiya, S. Fukui and K. Tanaka, Arch. Microbiol., 128, 215 (1980).

4) Y. Sakagami, A. Isogai, A. Suzuki, C. Kitada and M. Fujino, Agric. Biol. Chem., 43, 2643 (1979).

5) E. Tsuchiya, S. Fukui, Y. Kamiya, Y. Sakagami and M. Fujino, Biochem. Biophys. Res. Commun., 85, 459 (1978).

6) I. Kaneko, Y. H.-Shimada and A. Endo, Eur. J.
Biochem., 87, 313 (1978).

7) T. Miyakawa, T. Kadota, Y. Okubo, T. Hatano, E. Tsuchiya and S. Fukui, J. Bacteriol., 158, 814 (1984).

8) A. Endo, M. Kuroda and Y. Tsujita, J. Antibiot., 29, 1346 (1976).

9) A. Endo, "Methods in Enzymology," Vol. 72, ed. by J. M. Lownstein, Academic Press Inc., New York, N.Y., 1981, p. 684.

10) T. Miyakawa, M. Tabata, E. Tsuchiya and S. Fukui, Eur. J. Biochem., in press.

11) Y. Tomiyoshi, T. Miyakawa, E. Tsuchiya and S. Fukui, Agric. Biol. Chem., 45, 1917 (1981).

12) R. T. Swank and K. D. Munkres, Anal. Biochem., 39, 462 (1971).

13) A. Takatsuki, K. Kohno and G. Tamura, Agric. Biol. Chem., 39, 2089 (1975). 